\title{
BREVE DEPOIMENTO SOBRE A REVISTA ORPHEU
}

Cleonice Berardinelli ${ }^{1}$

Nota da organização: Em razão do centenário da revista Orpheu, a Professora Doutora Gilda da Conceição Santos gravou um depoimento da Professora Doutora Cleonice da Motta Berardinelli, pioneira dos estudos pessoanos no Brasil e sem a qual nosso congresso comemorativo "100Orpheu" não estaria completo. Agora trazemos uma versão transcrita e editada de sua fala para a seção de entrevistas da edição sobre "Modernismos" da Revista Desassossego.

\section{Parte I}

É muito importante na história da Literatura Portuguesa, principalmente da Literatura Portuguesa Moderna, a presença de uma revista que foi criada pela geração de Fernando Pessoa e Mário de Sá Carneiro. Sempre me perguntei: por que Orpheu? Orpheu é aquele que ama Eurídice e Eurídice é aquela que é arrancada aos olhos de Orpheu e levada para longe, onde ele não a pode alcançar. Há uma bela ópera chamada Orfeo ed Euridice, de Gluck, e me lembro que em uma das mais belas Arias dizia:

\section{Che farò senza Euridice?}

Dove andrò senza Il mio bene?

Che farò? Dove andrò?

Che farò senza il mio bene?

A revista Orpheu, no primeiro número, tem esta capa:

Esta capa nos dá Eurídice e as duas velas acesas que são a representação, pobre, naturalmente, mas expressiva, do inferno. Quando Orpheu vai conseguindo tirá-la do inferno, ela é arrebatada. Nesta imagem temos Eurídice com os braços abertos querendo resistir e sendo arrastada. Orpheu é um apaixonado sem remédio e, naturalmente, os poetas daquele tempo consideraram que era um símbolo expressivo para a situação deles, que, por sua vez, também eram apaixonados sem remédio por uma

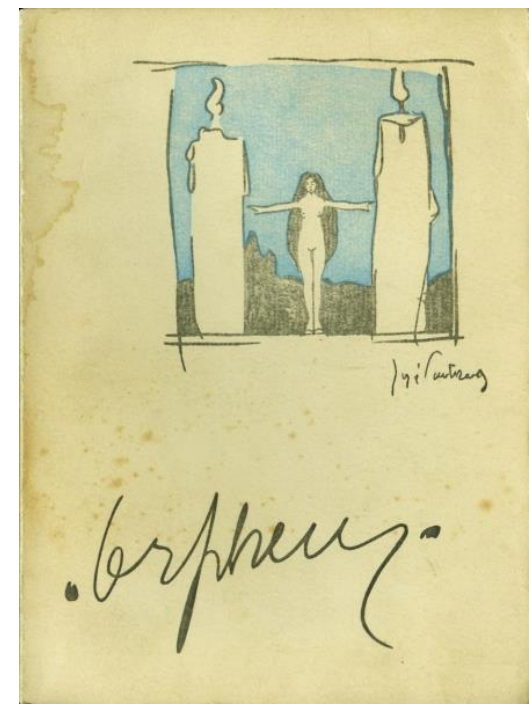
poesia que queriam salvar e, no entanto, parecia que se furtava aos seus braços. Esta é uma

${ }^{1}$ Professora emérita da Universidade Federal do Rio de Janeiro e da Pontifícia Universidade Católica do Rio de Janeiro, além de membro da Academia Brasileira de Letras. 
interpretação minha. Se estiver errada, recebam-na assim como está com toda minha franqueza.

No segundo número, coisas mais escandalosas que no primeiro. Por exemplo, aparecem os "Poemas Inéditos", de Angelo de Lima, que era louco. Um louco genial que consegue escrever alguns poucos sonetos muito bons e muito expressivos, dignos do estado de espírito de um louco. Uma poesia tão importante que até acho que os estudiosos de psiquiatria deviam ler e utilizar-se dele.

Aparecem também os "Poemas sem suporte", de Mário de Sá Carneiro. Esse não era nada louco, mas alguém que andava resvalando na beiradinha da loucura. "Poemas", de Eduardo Guimaraens, também. A novela vertígica, de Raul Leal, na mesma linha desta loucura que vai invadindo os poetas desse tempo. Violante de Cysneiros, uma personalidade que não existe, foi criada por eles para incluir o poema de uma mulher. "Ode Marítima", por Álvaro de Campos. "Narciso", poema de Luís de Montalvor. "Chuva Oblíqua": poemas interseccionistas de Fernando Pessoa. O mais importante para mim do segundo número, porque é um verdadeiro movimento criado por Fernando Pessoa, escandalosamente moderno, com estes poemas que trazem uma intersecção de planos que são dois e que começam assim:

Atravessa esta paysagem o meu sonho d'um porto infinito E a côr das flôres é transparente de as velas de grandes navios Que largam do caes arrastando nas aguas por sombra Os vultos ao sol d'aquellas arvores antigas...

Eu, quando li isso pela primeira vez, fiquei assaltada de dúvidas linguísticas que me perturbaram muito. Depois fui eu mesma procurando traduzir isto para mim e entendi. "A cor das flores tem a transparência das velas de grandes navios" Isso seria prosaicamente certo e inteligível, mas não é isso que ele quer, e sim, criar uma confusão na mente do leitor. 


\section{ORPHFU}

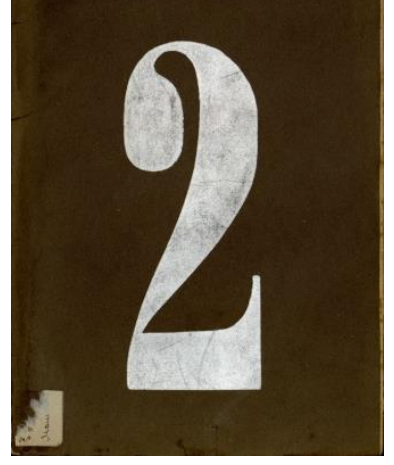

\section{Parte II}

Acho que foi um marco por ser "a" revista do movimento. Uma revista que saiu com esse impacto. A capa do primeiro número é impactante e, depois, a capa do segundo já abrandando o impacto inicial, mas, de certo modo, pondo aquele “2", como quem diz: "Isto é o sinal que pretendemos continuar o nosso caminho por aqui com estes poemas deste gênero!”. Acho eu, suposições.

Orpheu 3 é apenas uma pálida lembrança de que houve Orpheu 1 e 2. É importante porque entra em uma trilogia, na qual aparece como terceiro volume. No entanto, acho que não tem significado mais nítido, mais claro de uma individualidade. Já tinha passado o tempo de Orpheu. O grande tempo fora o dos números anteriores. O terceiro poderia ou não ter existido.

Para terminar, leio o poema Apoteose de Mário de Sá Carneiro, da Orpheu 1.

\section{APOTEOSE}

Mastros quebrados, singro num mar d'Ouro

Dormindo fôgo, incerto, longemente...

Tudo se me igualou num sonho rente,

E em metade de mim hoje só móro...

Sảo tristezas de bronze as que inda chóro -

Pilastras mortas, marmores ao Poente...

Lagearam-se-me as ansias brancamente

Por claustros falsos onde nunca óro...

Desci de mim. Dobrei o manto d'Astro,

Quebrei a taça de cristal e espanto,

Talhei em sombra o Oiro do meu rastro...

Findei... Horas-platina... Olor-brocado...

Luar-ansia... Luz-perdẩ... Orquideas pranto...

—Ó pantanos de Mim — jardim estagnado... 
Com esta leitura, espero que eu tenha conseguido transmitir o meu entusiasmo pelo que há em Orpheu, pela novidade real que vem dentro das folhas do primeiro e do segundo número da revista. Se consegui transmiti-lo, acho que cumpri o meu dever. Muito obrigada. 